\title{
MODELING LABOR DEMAND IN A STATE ECONOMETRIC MODEL
}

\author{
Max E. Jerrell and James M. Morgan
}

\section{Introduction}

The demand for labor services is an important component of most state and regional econometric models. Labor demand equations provide results with important forecasting and policy implications. These equations take on an added importance in regional modeling because the quantity of labor utilized is measured with greater frequency, accuracy and directness than are other, broader measures of economic performance. In fact, in many quarterly regional models, labor utilization serves as the principal measure of aggregate economic activity. Despite the crucial role played by labor demand equations, they have received limited attention from regional modelers, and virtually no studies have examined systematically the impact of the specification of labor demand equations on model performance.

This paper presents labor demand equations based on the Nadiri and Rosen $(1969,1973)$ theory of interrelated factor demand. These labor demand equations form a portion of a quarterly regional econometric model of the State of Arizona (Jerrell 1984). Dynamic properties of the model are explored, and ex-post forecasting results of the model are compared to results obtained using a more traditional labor demand specification. The organization of the paper is as follows. Section 2 reviews alternative specifications commonly used in modeling regional labor demand equations. Section 3 summarizes the Nadiri and Rosen (N-R) model of factor demand and presents the specification for the labor demand equations of the model used here. Section 4 presents empirical estimates and simulation results. Section 5 provides a brief summary of the study.

\section{Labor Demand Specification in Contemporary Regional Models}

While it is not uncommon for regional econometric models to use ad hoc labor demand specifications not formally derived from a production function, see for instance Hall and Licari (1974) and Chang (1979), most

\footnotetext{
-Associate Professor of Economics, Northern Arizona University and Professor of Computer Information Systems, Northern Arizona University.
}

recent regional models have made explicit use of production functions in labor demand modeling (Bolton 1985). The most commonly used production functions have been Cobb-Douglas and especially the constant elasticity of substitution (CES) production function. Assuming that the first order cost minimization condition that the marginal revenue product of labor equals the real wage is met, it can be shown that the demand for labor can be derived from a CES production function as an equation of the form

$$
\operatorname{Ln} L_{t}=a_{0}+a_{1} T_{t}+a_{2} \operatorname{Ln} Q_{1}+a_{3} L n W_{t}
$$

where $Q$ is output, $L$ is the demand for labor services, $T$ is the level of technology, W is the real wage, and the $a_{1}$ are parameters (Jerrell, 1984, pp. 81-3). The specification in equation 1 is valid only for a competitive industry in equilibrium. This specification appeals to regional modelers largely because it allows estimation of the demand for labor without capital stock, which is very difficult to measure at the regional level, as an explanatory variable.

For a variety of reasons, firms, or industries may not adjust immediately to the desired equilibrium. Delays in the adjustment to the equilibrium employment level can be incorporated into the model using a partial adjustment, or Koyck lag, mechanism which requires that the lagged value of the dependent variable be added to the set of explanatory variables in equation 1. This type of partial adjustment mechanism has been specified in such prominent regional models with annual observation periods as Adams, Brooking and Glickman (1975) and Rubin and Erickson (1980), and in virtually all quarterly regional models (Ratajczak, 1972, and Latham, Landes and Lewis, 1979).

Data availability and reliability issues cannot be ignored in the process of developing a regional model. Capital stock estimates normally cannot be generated at the regional level, except in manufacturing. Where the manufacturing capital stock is estimated the estimate is based on annual investment data. Gross regional product estimates derived from fragmentary sources by such indirect measures as regional ratios to national variables are the only available output measures. (Kendrick and Jaycox, 1965, and Weber, 1979). Many of the data required to generate these estimates are annual series. Thus output cannot be 
measured with great precision in regional models and it generally cannot be measured more than once per year.

Given the limitations of data on capital stock and output, some modelers have argued for the use of quarterly models based on employment and personal income data. As Engle notes, "forecasts of measurable employment are of more interest than forecasts of unmeasurable output" (Engle, 1980,p. 125). Another proponent of this approach argues that annual models cannot capture the timing pattern of regional adjustments to national stimuli and may obscure the impacts of short run changes in regional activity that are responsible for longer term movements, Ratajczak (1974).

The model presented in this paper is designed primarily for use in short-run forecasting, therefore a quarterly observation period is used. This requires modification of the specification in Equation 1, since the level of output, $Q$, is not available. If output data were available a typical output equation would specify $Q$ as a function of $D$, where $\mathrm{D}$ represents the demand for the products produced by the industry or sector in question. The nature of the demand variable would depend upon the sector being modeled. Some national aggregate such as GNP would be appropriate for basic industries, while regional personal income might be used for nonbasic industries. If industry output can be assumed to be a linear function of demand, the demand variable can be substituted into Equation 1 giving a derived demand for labor equation of the form

$$
\begin{aligned}
\operatorname{Ln} L_{t}= & b_{0}+b_{1} T_{t}+b_{2} \operatorname{Ln} D_{t}+ \\
& b_{3} \operatorname{Ln} W_{t}+(1-p) \operatorname{Ln~L~}_{t-1} .
\end{aligned}
$$

The partial adjustment mechanism described above has been specified in this equation by including $L_{k-1}$ as an explanatory variable.

Contemporary quarterly regional models are likely to use a specification very similar to Equation 2. The quantity of labor may be measured as the number of employees or as the number of manhours.

\section{A Specification Based on Interrelated Factor Demand}

The Nadiri and Rosen (1973) model of the demand for factors of production provides two insights that are important in structuring labor demand equations for regional models. First, they argue that total factor use consists of both stock and utilization rate components, with the stocks of labor and capital being the employment level and the capital stock, respectively, and average hours per week and the rate of capital services per unit of stock representing the utilization rate. Secondly, Nadiri and
Rosen contend that, in disequilibrium, the factor adjustment paths over time are interrelated.

The first contention of Nadiri and Rosen suggests that it is important that employment and average hours be estimated directly, since they represent the two dimensions of labor demand. Total manhours then can be derived from the identity manhours equals employment times average hours. This type of specification can be modeled through a Cobb-Douglas production function that in logarithmic form appears as

$$
\operatorname{Ln} Q_{t}=\operatorname{Ln} A+b_{1} \operatorname{Ln} E_{t}+b_{2} \operatorname{Ln} H_{t}+b_{3} \operatorname{Ln} K_{t}
$$

where $\mathrm{Q}$ is output, $\mathrm{E}$ is employment, $\mathrm{H}$ is average hours, $\mathrm{A}$ and the $b_{i}$ are parameters, and the stock and utilization rate of capital have been collapsed into a single variable, $K$, the capital services utilization rate. Total production costs per period, $\mathrm{C}$, will be

$$
\mathrm{C}=\mathrm{wE}_{\mathrm{t}} \mathrm{H}_{\mathrm{t}}+\mathrm{sE} \mathrm{E}_{\mathrm{t}}+\mathrm{cK}
$$

where $w$ is the wage rate per hour and is a function of $\mathrm{H}, \mathrm{c}$ is the user cost of capital, and $s$ is the amortized cost per employee of hiring, training, fringe benefits, and other labor costs that are independent of hours worked.

In long run equilibrium factor demand is obtained by minimizing cost with respect to the three factors of production, subject to the production function constraint. The path toward equilibrium may be modeled by a stock adjustment process similar to that specified in the preceding section. Nadiri and Rosen argue that the adjustment paths of the factors of production must be interrelated. They assume that firms always operate on their production functions. Thus if use of one factor is below its long run equilibrium at some point, the use of at least one of the other factors must be above its long run equilibrium, and the time paths of the factors must be interrelated. This leads to a specification that allows the demand for any factor to be stated as a function of the level of output, a vector of factor prices and a vector of lagged factor use.

Hanseman (1986) applied this type of labor demand model at the regional level using quarterly data for the Cincinnati SMSA. He split capital and labor into stock and utilization rate variables, but measured only one factor price, the real wage. Hanseman noted that very few of the coefficient estimates derived from this model were significantly different from zero, and proceeded to develop an alternative model in which lags of up to four quarters were permitted in specifying stock adjustment relationships. Ad hoc methods then were used to determine which lagged variables to retain.

Although the results of the Hanseman study are of 
interest, the limitations of his approach prevent them from addressing the issues raised in this paper. His estimates were derived only for the manufacturing sector, they were not connected to an econometric model of the region, and they relied on quarterly capital stock and utilization rate estimates whose construction required extensive assumptions.

Measures of the capital stock, and all factor prices except the wage rate are not readily available at the regional level. While this is a significant limitation, it is encountered often. Nadiri and Rosen (1973) used time as a proxy for capital stock in several empirical equations. To avoid attempting to construct data series from limited and indirect sources, $\mathrm{K}, \mathrm{s}$, and $\mathrm{c}$ will be omitted from the system. Time, $T$, is reintroduced as a measure of the level of technology and the long term trend in capital stock, although we do not suggest that it is a fully appropriate proxy for the capital stock. In addition, output demand, D, replaces $Q$ on the assumption that output is a linear function of demand. The final specifications for the labor demand equations based on the Nadiri and Rosen model are

$$
\begin{aligned}
\operatorname{Ln} E_{t}= & C_{0}+C_{1} T+C_{2} \operatorname{Ln} D_{t}+C_{3} \operatorname{Ln} W_{t}+ \\
& C_{4} \operatorname{Ln} E_{t-1}+C_{5} \operatorname{Ln} H_{t-1}
\end{aligned}
$$

and

$$
\begin{aligned}
\operatorname{Ln} H_{t}= & D_{0}+D_{1} T+D_{2} \operatorname{Ln} D_{t}+D_{3} \operatorname{Ln} W_{t}+ \\
& D_{4} \operatorname{Ln} E_{t-1}+D_{5} \operatorname{Ln} H_{t-1}
\end{aligned}
$$

where the hours measure is average quarterly hours.

If the contentions of Nadiri and Rosen are correct, Equations 5 and 6 are preferable to the labor demand specifications commonly used in regional models in two important respects. First, they decompose total demand for labor services into its stock (employment) and utilization rate (hours) components whereas the typical regional model specification, e.g. Equation 2, does not. Second, Equations 5 and 6 permit more flexible dynamic properties by allowing different but interrelated adjustment paths for the hours and employment components of the demand for labor services. Equation 2 provides only one type of adjustment, a monotonic increase or decrease to the new equilibrium; Equations 5 and 6 can produce several time adjustment paths, and it is possible for these time adjustment paths to vary substantially across industries.

\section{Model Estimation, Simulation, and Testing}

This section summarizes the empirical estimation, simulation, and testing results of the model. First, the regression results for the labor demand equations are presented, then the dynamic properties of the model are analyzed and, finally, some ex-post forecasting results are presented and compared to results for an alternative model using labor demand equations specified as in Equation 2.

\section{Empirical Specification Results}

The labor demand equations of the model are presented in Tables 1 and 2. The model contains additional equations representing the remainder of the Arizona economy. A schematic of the model is presented in Figure 1. Employment and hours equations are specified for each of eight industrial sectors; manufacturing, mining, contract construction, TCU (transportation, communications, and utilities) wholesale trade, retail trade, FIRE (finance, insurance and real estate) and services. The employment equations are represented by the Employee Demand block and the hours equations are represented by the Average Hours block in Figure 1.

The explanatory variables in the employment and hours equations are consistent with the specifications of Equations 5 and 6 above. Only the measures of demand for industry output vary across industries and only this component of the specification requires elaboration. Manufacturing and mining are assumed to be basic industries with demands for output depending on national variables, U.S. real GNP and U.S. nonferrous metal consumption, respectively. Demand for output in the contract construction industry is assumed to follow a flexible accelerator model in which demand is a function of both the current level of real Arizona personal income and its rate of change. All other sectors are assumed to be nonbasic with demands dependent upon real Arizona personal income.

Feedback between the employment and hours equations and the remainder of the model comes from two directions. Average hours worked times employment gives labor demand in manhours. Labor demand times wage rate equals wage income, by sector, which is added across the sectors to obtain total wage income. Wage income is a component of state personal income which feeds back as an output demand variable in the employment and hours equations for nonbasic industries. The second feedback loop is through the sum of employment across sectors serving as an explanatory variable in the unemployment rate equation, which affects wage rates, which in turn affectemployment and hours in each industry sector. The equations for blocks of the model other than employment and hours generally are similar to those in other recent quarterly regional models and are not presented here, see Jerrell (1984) for details.

Employment equations are presented in Table 1 and the hours equations in Table 2. The appropriate T statistic 


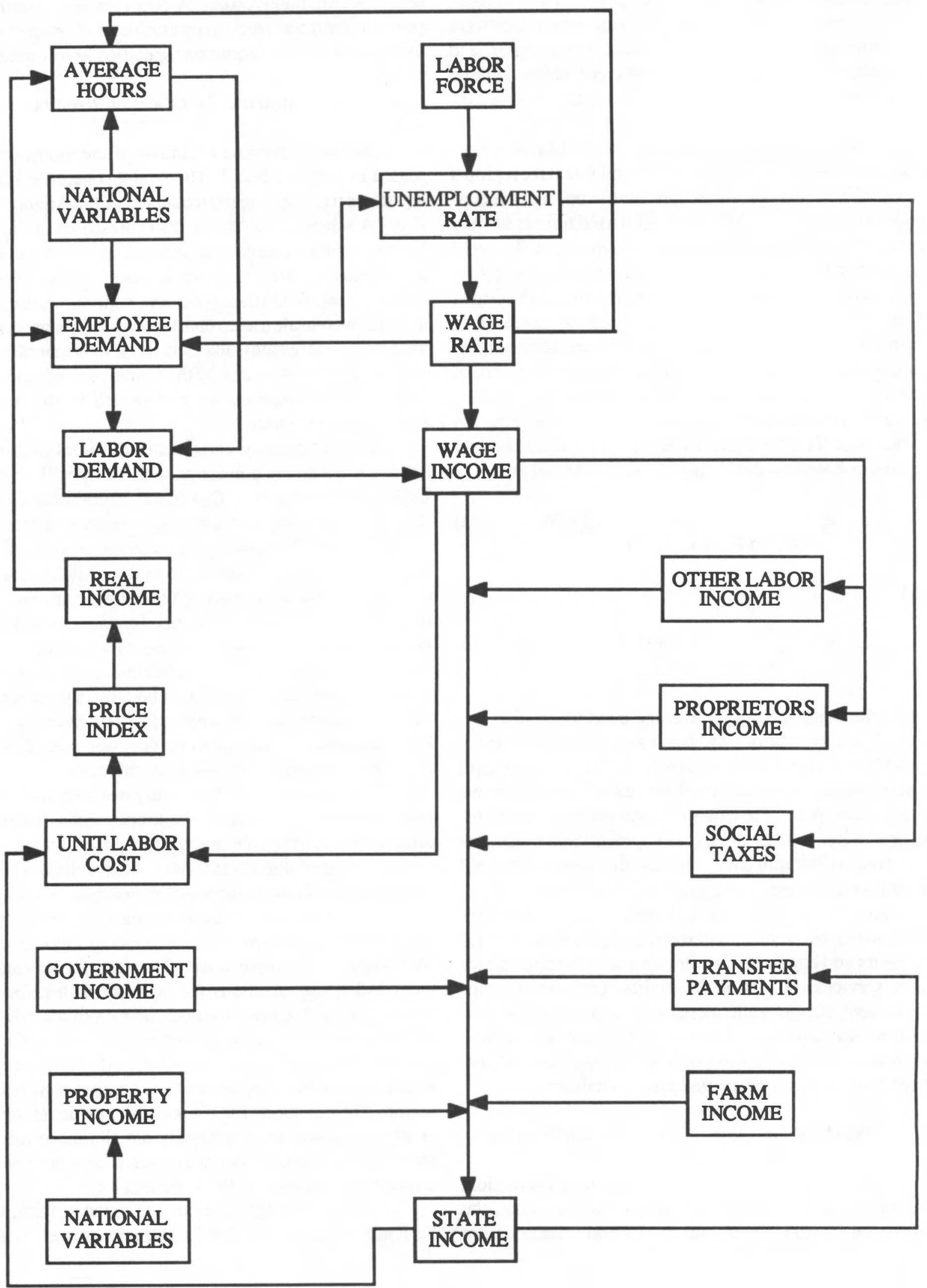

Figure One 
is presented in parentheses below each coefficient. $\mathbf{R}^{2}$ statistics for each equation also are presented. The output demand variables have positive and statistically significant coefficients in all of the employment equations except contract construction. In the contract construction industry the change in real personal income has the expected positive coefficient and it is statistically significant, while the level of real personal income has an unexpected negative coefficient. The signs on the output demand variables are identical in the hours equations of Table 2, although their impact is less significant. Only three of the hours equations include a statistically significant output demand coefficient. The coefficient on time varies widely across industry sectors with respect to both sign and significance. This is not surprising since the time variable is expected to reflect the trend in capital stock, which could be increasing or decreasing. The real wage coefficients are negative as expected for all equations except employment in mining and employment and hours in FIRE, and only employment in FIRE has a statistically significant wage equation of unexpected sign.

The pattern of coefficients on the lagged dependent variables varies across industries. The coefficient on the own lagged variable is positive and in the unit interval for all equations, and is statistically significant for all equations except hours in contract construction. The coefficient on lagged hours is negative in six of the eight employment equations, with four of the negative coefficients being statistically significant. Five of the eight lagged employment coefficients in the hours equations are negative, but only one is statistically significant. None of the positive coefficients on these lagged cross terms is statistically significant. These lagged adjustment coefficients cannot be interpreted in isolation, but derive their importance from their impact on the dynamic properties of the model.

\section{Dynamic Properties}

There is no implied theoretical restriction on the sign of the cross lag terms in the employment and hours equations, and the observed signs on these terms vary across industries. The time path to equilibrium may be one of monotonic convergence $(M)$, a variable may overshoot its equilibrium initially and then converge monotonicly $(O)$, a variable may move farther from equilibrium initially and then converge monotonicly $(\mathrm{A})$, or values may cycle about equilibrium with a cycle of any length $(C)$. The average hours and employment equations for each industry form a set of linear difference equations. If the characteristic vector of a set of difference equations contains complex roots, the system will exhibit cyclical dynamic behavior
(Chow 1975, p. 27-29). Complex roots were found among the characteristic vectors for two industries, transportation and services, indicating that the average hours and employment equations for those industries will exhibit a cyclical time path to convergence.

The speed with which employment and hours adjust toward equilibrium can be studied most effectively by a simplecomputer simulation. The simulation program used examines the path to equilibrium when a variable has been displaced one unit above its equilibrium position.

The simulation results are summarized in Table 3. The time paths of both average hours and employment are presented. The table indicates the time in quarters required to reach 90 percent of convergence and the type of convergence path exhibited. Where the cyclical convergence path is found the length of the cycle in quarters also is indicated.

The simulations compared the results of base runs with runs where the system had been subjected to an exogenous shock. The base run was constructed by holding all exogenous variables constant and letting the model reach an equilibrium defined as occurring when all variables reach a constant value. All simulation runs used values calculated by the model for the lagged endogenous variables.

The runs including an exogenous shock were constructed by increasing the level of the output variable of a particular industrial division by 1 percent. This 1 percent increase was maintained over the entire simulation period until the system again reached equilibrium. The time to 90 percent convergence was found by determining when the simulated variable stayed within an interval about its final value. This interval was calculated to be plus or minus 10 percent of the difference between the value of the variable produced by the base run and its value produced by the shocked run.

Table 3 indicates that the hours equations achieved 90 percent adjustment more rapidly than the employment equations in four of the industrial sectors, and employment reaches 90 percent convergence more rapidly than hours in four sectors. Convergence in the employment equation for contract construction was so slow that percent convergence after 10 quarters rather than time to 90 percent convergence is presented in the table.

One would expect hours to be used extensively for short run adjustment in industries where the proportion of labor costs that is invariant with hours is relatively high. High fixed labor costs would be expected in industries with extensive fringe benefits and the higher hiring and severance costs often associated with unionized industries. The results found here are consistent with that expectation. Hours appear to be used extensively for short term adjust- 
Worker Employment in an Interrelated Factor Demand

Model of the Arizona Economy, 1969-1981

\begin{tabular}{|c|c|c|c|c|c|c|c|c|c|c|c|c|c|c|c|}
\hline \multirow[t]{2}{*}{ Sectors } & \multicolumn{6}{|c|}{ Dummy Variables } & \multicolumn{3}{|c|}{ Industry Variables } & \multicolumn{4}{|c|}{ Output Demand Variables } & \multirow[b]{2}{*}{$\mathbf{R}^{2}$} & \multirow[b]{2}{*}{ D.W. } \\
\hline & Intercept & $\begin{array}{c}\text { First } \\
\text { Quarter }\end{array}$ & $\begin{array}{l}\text { Second } \\
\text { Quarter }\end{array}$ & $\begin{array}{l}\text { Third } \\
\text { Quarter }\end{array}$ & $\begin{array}{l}\text { Coal } \\
\text { Strike }\end{array}$ & Time & $\begin{array}{c}\text { Log } \\
\text { Real } \\
\text { Wage }\end{array}$ & $\begin{array}{l}\text { Log } \\
\text { Lagged } \\
\text { Emp. }\end{array}$ & $\begin{array}{c}\text { Log } \\
\text { Lagged } \\
\text { Hours }\end{array}$ & $\begin{array}{l}\text { Log US } \\
\text { Real } \\
\text { GNP }\end{array}$ & $\begin{array}{c}\text { Log US } \\
\text { Nonferrous } \\
\text { Metal Cons. }\end{array}$ & $\begin{array}{c}\log \text { Az. } \\
\text { Real } \\
\text { P.I. }\end{array}$ & $\begin{array}{l}\text { Log Chg. } \\
\text { in Az. } \\
\text { Real P.I. }\end{array}$ & & \\
\hline Manufacturing & $\begin{array}{c}-4.058 \\
(-3.26)\end{array}$ & $\begin{array}{c}-0.013 \\
(-1.46)\end{array}$ & $\begin{array}{l}0.007 \\
(1.13)\end{array}$ & $\begin{array}{l}-0.004 \\
(-0.63)\end{array}$ & & $\begin{array}{l}-0.001 \\
(-1.56)\end{array}$ & $\begin{array}{r}-0.166 \\
(-1.06)\end{array}$ & $\begin{array}{c}0.797 \\
(20.27)\end{array}$ & $\begin{array}{r}0.040 \\
(0.15)\end{array}$ & $\begin{array}{l}0.618 \\
(5.64)\end{array}$ & & & & 0.99 & 1.35 \\
\hline Mining & $\begin{array}{l}3.548 \\
(1.88)\end{array}$ & $\begin{array}{c}-0.005 \\
(-0.18)\end{array}$ & $\begin{array}{r}0.010 \\
(0.33)\end{array}$ & $\begin{array}{r}0.002 \\
(0.05)\end{array}$ & $\begin{array}{r}0.215 \\
(-3.35)\end{array}$ & $\begin{array}{l}-0.0002 \\
(-0.18)\end{array}$ & $\begin{array}{r}0.052 \\
(0.21)\end{array}$ & $\begin{array}{r}0.470 \\
(5.13)\end{array}$ & $\begin{array}{r}-0.739 \\
(-2.10)\end{array}$ & & $\begin{array}{l}0.607 \\
(4.46)\end{array}$ & & & 0.82 & 1.32 \\
\hline $\begin{array}{l}\text { Contract } \\
\text { Construction }\end{array}$ & $\begin{array}{l}0.647 \\
(0.26)\end{array}$ & $\begin{array}{l}0.003 \\
(0.09)\end{array}$ & $\begin{array}{c}0.051 \\
(1.86)\end{array}$ & $\begin{array}{r}0.013 \\
(0.56)\end{array}$ & & & $\begin{array}{c}-0.477 \\
(-1.75)\end{array}$ & $\begin{array}{r}0.979 \\
(19.22)\end{array}$ & $\begin{array}{c}-0.240 \\
(-0.56)\end{array}$ & & & $\begin{array}{r}-0.120 \\
(-1.00)\end{array}$ & $\begin{array}{c}2.111 \\
(3.33)\end{array}$ & 0.96 & 1.45 \\
\hline TCU & $\begin{array}{r}-1.803 \\
(-3.38)\end{array}$ & $\begin{array}{c}-0.001 \\
(-0.11)\end{array}$ & $\begin{array}{r}0.013 \\
(2.84)\end{array}$ & $\begin{array}{l}0.007 \\
(1.52)\end{array}$ & & $\begin{array}{l}-0.0003 \\
(-0.49)\end{array}$ & $\begin{array}{r}-0.297 \\
(-3.80)\end{array}$ & $\begin{array}{r}0.519 \\
(5.87)\end{array}$ & $\begin{array}{r}0.083 \\
(0.85)\end{array}$ & & & $\begin{array}{l}0.474 \\
(6.25)\end{array}$ & & 0.99 & 2.19 \\
\hline Wholesale Trade & $\begin{array}{r}-0.740 \\
(-0.52)\end{array}$ & $\begin{array}{l}-0.005 \\
(-0.83)\end{array}$ & $\begin{array}{r}-0.003 \\
(-0.44)\end{array}$ & $\begin{array}{l}-0.025 \\
(-3.12)\end{array}$ & & $\begin{array}{l}0.0004 \\
(0.38)\end{array}$ & $\begin{array}{r}-0.620 \\
(-3.59)\end{array}$ & $\begin{array}{r}0.598 \\
(6.13)\end{array}$ & $\begin{array}{l}-0.291 \\
(-136)\end{array}$ & & & $\begin{array}{l}0.446 \\
(3.99)\end{array}$ & & 0.99 & 2.19 \\
\hline Retail Trade & $\begin{array}{c}1.536 \\
(1.37)\end{array}$ & $\begin{array}{r}-0.031 \\
(-2.95)\end{array}$ & $\begin{array}{c}-0.024 \\
(-2.83)\end{array}$ & $\begin{array}{c}-0.033 \\
(-4.38)\end{array}$ & & $\begin{array}{r}0.002 \\
(2.17)\end{array}$ & $\begin{array}{r}-0.231 \\
(-1.80)\end{array}$ & $\begin{array}{r}0.435 \\
(2.88)\end{array}$ & $\begin{array}{l}-0.236 \\
(-1.32)\end{array}$ & & & $\begin{array}{l}0.410 \\
(3.18)\end{array}$ & & 0.99 & 1.53 \\
\hline Services & $\begin{array}{r}4.165 \\
(1.94)\end{array}$ & $\begin{array}{l}-0.0001 \\
(-0.02)\end{array}$ & $\begin{array}{r}-0.000 \\
(-0.00)\end{array}$ & $\begin{array}{r}-0.013 \\
(-3.02)\end{array}$ & & $\begin{array}{r}0.003 \\
(2.03)\end{array}$ & $\begin{array}{r}-0.167 \\
(-1.65)\end{array}$ & $\begin{array}{c}0.641 \\
(5.90)\end{array}$ & $\begin{array}{l}-0.642 \\
(-1.88)\end{array}$ & & & $\begin{array}{l}0.196 \\
(2.69)\end{array}$ & & 0.99 & 1.79 \\
\hline FIRE & $\begin{array}{r}-6.479 \\
(-1.43) \\
\end{array}$ & $\begin{array}{r}-0.005 \\
(-0.98) \\
\end{array}$ & $\begin{array}{c}0.014 \\
(2.48) \\
\end{array}$ & $\begin{array}{c}0.014 \\
(2.46)\end{array}$ & & $\begin{array}{c}0.002 \\
(2.55)\end{array}$ & $\begin{array}{r}0.386 \\
(2.77)\end{array}$ & $\begin{array}{c}0.648 \\
(7.95)\end{array}$ & $\begin{array}{l}1.306 \\
(1.76)\end{array}$ & & & $\begin{array}{r}0.185 \\
(2.11)\end{array}$ & & 0.99 & 1.13 \\
\hline
\end{tabular}


Table 2

Hours Worked Equations in an Interrelated Factor Demand

Model of the Arizona Economy, 1969-1981

\begin{tabular}{|c|c|c|c|c|c|c|c|c|c|c|c|c|c|c|c|}
\hline \multirow[t]{2}{*}{ Sectors } & \multicolumn{6}{|c|}{ Dummy Variables } & \multicolumn{3}{|c|}{ Industry Variables } & \multicolumn{4}{|c|}{ Output Demand Variables } & \multirow[b]{2}{*}{$\mathbf{R}^{2}$} & \multirow[b]{2}{*}{ D.W. } \\
\hline & Intercept & $\begin{array}{c}\text { First } \\
\text { Quarter }\end{array}$ & $\begin{array}{l}\text { Second } \\
\text { Quarter }\end{array}$ & $\begin{array}{l}\text { Third } \\
\text { Quarter }\end{array}$ & $\begin{array}{l}\text { Coal } \\
\text { Strike }\end{array}$ & Time & $\begin{array}{l}\text { Log } \\
\text { Real } \\
\text { Wage }\end{array}$ & $\begin{array}{c}\text { Log } \\
\text { Lagged } \\
\text { Emp. }\end{array}$ & $\begin{array}{l}\text { Log } \\
\text { Lagged } \\
\text { Hours }\end{array}$ & $\begin{array}{l}\text { Log US } \\
\text { Real } \\
\text { GNP }\end{array}$ & $\begin{array}{c}\text { Log US } \\
\text { Nonferrous } \\
\text { Metal Cons. }\end{array}$ & $\begin{array}{c}\log A z . \\
\text { Real } \\
\text { P.I. }\end{array}$ & $\begin{array}{l}\text { Log Chg. } \\
\text { in Az. } \\
\text { Real P.I. }\end{array}$ & & \\
\hline Manufacturing & $\begin{array}{r}2.357 \\
(3.71)\end{array}$ & $\begin{array}{c}-0.011 \\
(-2.33)\end{array}$ & $\begin{array}{r}-0.001 \\
(-0.46)\end{array}$ & $\begin{array}{r}-0.005 \\
(-1.54)\end{array}$ & & $\begin{array}{l}0.0006 \\
(1.31)\end{array}$ & $\begin{array}{c}-0.308 \\
(-3.86)\end{array}$ & $\begin{array}{r}-0.077 \\
(-3.84)\end{array}$ & $\begin{array}{l}0.452 \\
(3.43)\end{array}$ & $\begin{array}{r}0.062 \\
(1.10)\end{array}$ & & & & $\begin{array}{l}0.75 \\
0.75\end{array}$ & $\begin{array}{l}1.88 \\
2.27\end{array}$ \\
\hline Mining & $\begin{array}{l}2.412 \\
(3.56)\end{array}$ & $\begin{array}{c}-0.022 \\
(-2.37)\end{array}$ & $\begin{array}{c}-0.012 \\
(-1.27)\end{array}$ & $\begin{array}{r}-0.013 \\
(-1.27)\end{array}$ & $\begin{array}{r}0.020 \\
(0.97)\end{array}$ & $\begin{array}{l}0.0006 \\
(1.73)\end{array}$ & $\begin{array}{r}-0.203 \\
(-2.61)\end{array}$ & $\begin{array}{r}-0.030 \\
(-1.03)\end{array}$ & $\begin{array}{r}0.501 \\
(4.45)\end{array}$ & & $\begin{array}{c}0.042 \\
(0.96)\end{array}$ & & & 0.75 & 2.27 \\
\hline $\begin{array}{l}\text { Contract } \\
\text { Construction }\end{array}$ & $\begin{array}{r}4.817 \\
(5.60)\end{array}$ & $\begin{array}{c}-0.006 \\
(-0.57)\end{array}$ & $\begin{array}{r}0.007 \\
(0.71)\end{array}$ & $\begin{array}{r}-0.003 \\
(-0.38)\end{array}$ & & & $\begin{array}{r}-0.339 \\
(-3.67)\end{array}$ & $\begin{array}{r}0.033 \\
(1.89)\end{array}$ & $\begin{array}{l}0.129 \\
(0.89)\end{array}$ & & & $\begin{array}{c}-0.133 \\
(-3.26)\end{array}$ & $\begin{array}{l}0.096 \\
(0.45)\end{array}$ & 0.47 & 1.87 \\
\hline TCU & $\begin{array}{r}2.364 \\
(4.06)\end{array}$ & $\begin{array}{l}0.014 \\
(2.99)\end{array}$ & $\begin{array}{r}-0.002 \\
(-0.43)\end{array}$ & $\begin{array}{l}0.014 \\
(2.78)\end{array}$ & & $\begin{array}{l}0.002 \\
(2.92)\end{array}$ & $\begin{array}{r}-0.487 \\
(-5.45)\end{array}$ & $\begin{array}{r}-0.533 \\
(-5.57)\end{array}$ & $\begin{array}{l}0.380 \\
(3.59)\end{array}$ & & & $\begin{array}{l}0.424 \\
(5.16)\end{array}$ & & 0.85 & 2.28 \\
\hline Wholesale Trade & $\begin{array}{l}2.006 \\
(2.28)\end{array}$ & $\begin{array}{l}-0.0004 \\
(1.73)\end{array}$ & $\begin{array}{l}-0.003 \\
(2.98)\end{array}$ & $\begin{array}{r}0.009 \\
(4.71)\end{array}$ & & $\begin{array}{l}-0.0004 \\
(-0.43)\end{array}$ & $\begin{array}{r}-0.143 \\
(-2.43)\end{array}$ & $\begin{array}{c}-0.090 \\
(-2.90)\end{array}$ & $\begin{array}{r}0.573 \\
(3.61)\end{array}$ & & & $\begin{array}{l}0.120 \\
(3.31)\end{array}$ & & 0.64 & 1.85 \\
\hline Retail Trade & $\begin{array}{r}2.105 \\
2.28)\end{array}$ & $\begin{array}{r}0.015 \\
(-0.43)\end{array}$ & $\begin{array}{r}0.021 \\
(2.98)\end{array}$ & $\begin{array}{r}0.029 \\
(4.71)\end{array}$ & & $\begin{array}{l}-0.0004 \\
(-0.43)\end{array}$ & $\begin{array}{c}-0.258 \\
(-2.43)\end{array}$ & $\begin{array}{c}-0.362 \\
(-2.90)\end{array}$ & $\begin{array}{r}0.535 \\
(3.61)\end{array}$ & & & $\begin{array}{c}0.353 \\
(3.31)\end{array}$ & & 0.77 & 2.23 \\
\hline Services & $\begin{array}{l}1.736 \\
(2.45)\end{array}$ & $\begin{array}{l}-0.0006 \\
(-0.43)\end{array}$ & $\begin{array}{c}-0.002 \\
(-1.15)\end{array}$ & $\begin{array}{l}-0.0003 \\
(-0.21)\end{array}$ & & $\begin{array}{l}-0.0007 \\
(-1.51)\end{array}$ & $\begin{array}{r}-0.017 \\
(-0.50)\end{array}$ & $\begin{array}{c}0.014 \\
(0.39)\end{array}$ & $\begin{array}{c}0.692 \\
(6.15)\end{array}$ & & & $\begin{array}{c}0.006 \\
(0.25)\end{array}$ & & 0.97 & 1.80 \\
\hline FIRE & $\begin{array}{r}3.944 \\
(4.32)\end{array}$ & $\begin{array}{l}-0.0002 \\
(-0.18)\end{array}$ & $\begin{array}{r}-0.001 \\
(-0.88)\end{array}$ & $\begin{array}{l}-0.0002 \\
(-0.21)\end{array}$ & & $\begin{array}{l}-0.0003 \\
(-0.17)\end{array}$ & $\begin{array}{c}0.014 \\
(0.50)\end{array}$ & $\begin{array}{c}-0.008 \\
(-0.46)\end{array}$ & $\begin{array}{c}0.376 \\
(2.52)\end{array}$ & & & $\begin{array}{r}-0.005 \\
(-0.27)\end{array}$ & & 0.78 & 2.23 \\
\hline
\end{tabular}


Table 3

Employment and Hours Equilibrium Convergence Results from an Interrelated Factor Demand Model of the Arizona Economy, 1969-1981

\begin{tabular}{|c|c|c|c|c|}
\hline \multirow[t]{2}{*}{ Industry } & \multicolumn{2}{|c|}{ Employment } & \multicolumn{2}{|c|}{ Hours } \\
\hline & $\begin{array}{l}\text { Time to } 90 \% \\
\text { Convergence }\end{array}$ & $\begin{array}{l}\text { Type of } \\
\text { Path* }\end{array}$ & $\begin{array}{l}\text { Time to } 90 \% \\
\text { Convergence }\end{array}$ & $\begin{array}{l}\text { Type of } \\
\text { Path" }\end{array}$ \\
\hline Manufacturing & 10 & $\mathbf{M}$ & 2 & 0 \\
\hline Mining & 6 & 0 & 4 & 0 \\
\hline $\begin{array}{l}\text { Contract } \\
\text { Construction }\end{array}$ & $47 \% * *$ & $\mathbf{M}$ & 2 & $\mathbf{M}$ \\
\hline TCU & 3 & C 15 & 5 & C 15 \\
\hline Wholesale Trade & 2 & $\mathbf{M}$ & 4 & $\mathbf{M}$ \\
\hline Retail Trade & 2 & $\mathbf{M}$ & 4 & $\mathbf{M}$ \\
\hline FIRE & 3 & $\mathbf{A}$ & 7 & $\mathbf{M}$ \\
\hline Services & 11 & C 20 & 6 & C 20 \\
\hline
\end{tabular}

\footnotetext{
- M - monotonic

O - initial overadjustment followed by monotonic convergence

A - initial movement away from equilibrium followed by monotonic convergence

C - cyclical convergence path, cycle time in quarters

*. This entry indicates the percentage of convergence achieved after 10 quarters.
}

ment in the manufacturing, mining, and contract construction sectors, and these are characterized by relatively extensive unionization and high fringe benefit costs.

The time required for 90 percent adjustment for hours differed from that for employment for every industry and in some cases the convergence time differences were quite large. This suggests that the Nadiri and Rosen contention that the stock and utilization components of labor services may follow different paths to equilibrium is well taken.

The type of path results include examples of each of the convergence paths described above. TCU and Services exhibit cyclical paths with cycle lengths of 15 and 20 quarters, respectively. Manufacturing hours and mining employment initially overshoot and then converge monotonicly. Employment in the FIRE sector initially moves farther from equilibrium and then converges rapidly and monotonicly.

\section{Ex-Post Simulation Results}

For purposes of comparison an alternative specifica- tion of the Arizona econometric model was developed using industry employment and total manhours equations specified as in Equation 2 above. All equations except those for labor demand by industry were identical across the two specifications. Ex-post simulations of the two model specifications were generated over the entire first quarter 1969 through third quarter 1981 sample period. The simulations used actual values of all exogenous variables and lagged endogenous variables and the parameter estimates to predict current period endogenous variable values. Mean absolute percentage error, MAPE, and mean squared error, MSE, values were calculated for each of the endogenous variables of the model and for several aggregate variables.

The performance of the alternative specifications in predicting such economic aggregates as total employment and personal income provides the most comprehensive measure available of the relative performance of the models. To that end the MAPE and MSE values for the unemployment rate, total employment and total personal income are presented in Table 4. For each of these variables, the MAPE and MSE values were smaller for the 
Table 4

Ex-post Simulation Errors from Two Econometric Models of the Arizona Economy

\begin{tabular}{ccccc}
\hline \hline Item & \multicolumn{2}{c}{$\begin{array}{c}\text { Interrelated } \\
\text { Factor Demand } \\
\text { Model }\end{array}$} & \multicolumn{2}{c}{$\begin{array}{c}\text { Altemative } \\
\text { Model }\end{array}$} \\
\hline & MAPE* & MSE** & MAPE & MSE \\
Unemployment Rate & 0.1275 & 00.5531 & 0.1331 & 00.5531 \\
Total Employment & 0.00066 & 44.33 & 0.00069 & 47.88 \\
Personal Income & 0.0067 & 1784.00 & 0.0078 & 1850.00 \\
\hline
\end{tabular}

* Mean absolute percentage error.

**Mean squared error.

interrelated factor demand model presented here than for the alternate specification based on Equation 2. This suggests that the interrelated factor demand specification provides a modest but consistent improvement in overall model accuracy compared to a labor demand specification typical of contemporary regional models.

\section{Summary}

This paper presents a specification for the labor demand equations of a regional econometric model based on the work of Nadiri and Rosen. The specification divides labor demand into stock (employment) and utilization (average hours) components. The two components follow different but interrelated paths to equalibrium.

The empirical results support the contention that labor demand has stock and utilization dimensions that may respond in different ways to various economic stimuli. The time required to achieve 90 percent convergence to equalibrium after a unit disturbance was different for hours than for employment in all industries and this difference was substantial in several cases. Hours adjusted more rapidly than employment in the manufacturing, mining, contract construction, and services sectors, while the opposite was true in the transportation, wholesale trade, retail trade and FIRE sectors. The results presented here also support the idea that the time paths of the two components of labor demand are interrelated. The coefficient on lagged hours was statistically significant in half of the employment equations and the presence of the lagged value of hours in the employment equations materially influenced the dynamic behavior of employment. The time path of employment was cyclical for the transportation and services sectors.
Ex-post test results for aggregate economic variables indicate that an econometric model based on this specification provided a modest but consistent reduction in forecast error in unemployment, total employment and personal income, when compared to a model using labor demand equations typical of current regional modeling practice.

The promising results provided by this specification suggest that further work using the interrelated factor demand model is needed. The model presented in this paper admittedly was mis-specified. Capital stock and capital utilization rate were not included in the model. In addition, only one factor price variable, the real wage, was utilized. The addition of the capital stock and its utilization rate and the full set of factor price variables, if reliably measured, would provide a much clearer test of the notion of interrelated factor demand espoused by Nadiri and Rosen. While reliable measurement of these variables will not be achieved easily, the return in improved forecast accuracy and understanding of regional economic systems may be substantial.

\section{Note}

1Shapiro and Fulton (1985) used a specification similar to this in their model of the Detroit SMSA. They based their specification on a synthesis of several formulations of labor demand including the Nadiri and Rosen work. Thus their specification includes some variables not due to Nadiri and Rosen. In addition, they chose the change in employment and change in hours as their dependent variables rather than the levels of these variables.

\section{References}

Adams, Gerald, Carl Brooking and Norman Glickman. "On the 
Specification and Simulation of a Regional Econometric Model: A Model of Mississippi." Review of Economics and Statistics. 57 (1975). 286-298.

Bolton, Roger. "Regional Econometric Models." Journal of Regional Science. 25 (1985), 495-521.

Chang, Semoon. "An Econometric Forecasting Model Based on Regional Economic Information System Data: The Case of Mobile Alabama." Journal of Regional Science. 19 (1979), 437-447.

Chow, Gregory. Analysis and Control of Dynamic Economic Systems. New York: J. Wiley and Sons, 1975.

Engle, Robert. "An Exploratory Policy-Oriented Econometric Model of a Metropolitan Area: Boston, " in Lawrence Klein et. al. (eds.). Quantitative Economics and Development: Essays in Memory of Ta-Chung Liu. New York: Academic Press, 1980.

Hall, Owen, and Joseph Licari. "Building Small Region Econometric Models: Extension of Glickman's Structure to Los Angeles." Journal of Regional Science. 14 (1974). 337-353.

Hanseman, Dennis. "A Quarterly Econometric Model of Factor Demands in Regional Manufacturing." Journal of Regional Science. 26 (1986). 161-177.

Jerrell, Max. "An Econometric Model of Arizona." Unpublished Ph.D. dissertation. Arizona State University, 1984.

Kendrick, J. W., and C. L. Jaycox. "The Concept and Measurement of Gross State Product." Southern Economic Journal.
32 (1965). 153-168.

Latham, William, Kenneth Lewis, and John Landon. "Regional Econometric Models: Specification and Simulation of a Quarterly Alternative for Small Regions." Journal of Regional Science. 14 (1979), 1-13.

Nadiri, M. Ishag, and Sherwin Rosen. "Interrelated Factor Demand Functions." American Economic Review. 59 (1969). 457-471.

- ADisequilibrium Model of the Demand for the Factors of Production. New York: National Bureau of Economic Research. 1973.

Ratajczak, Donald. “A Quarterly Econometric Model for California." Mimeo, University of California Los Angeles. 1972. ."Data Limitation and Alternative Methodology in Estimating Regional Econometric Models." Review of Regional Studies 4 (1974). 51-64.

Rubin, Barry, and Rodney Erickson. "Specification and Performance Improvements in Regional Econometric Forecasting Models: A Model for the Milwaukee Metropolitan Area. "Joumal of Regional Science. 20 (1980). 11-35.

Shapiro, Harold, and George Fulton. A Regional Econometric Forecasting System. Ann Arbor MI: University of Michigan Press. 1985.

Weber, Richard. "A Synthesis of Methods Proposed for Estimating Gross State Product." Journal of Regional Science. 19 (1979). 217-230. 